\title{
Numerical Analysis of Temperature Distributions in Single Cell of Polymer Electrolyte Fuel Cell when Operated in Elevated Temperature Range
}

\author{
Akira Nishimura ${ }^{1}$, Kanji Patoriki Zamami ${ }^{1}$, Masato Yoshimura ${ }^{1}$, Masafumi Hirota ${ }^{1}$ and Mohan Lal Kolhe ${ }^{2}$ \\ 1. Division of Mechanical Engineering, Graduate School of Engineering, Mie University, Tsu-city, Mie 514-8507, Japan \\ 2. Faculty of Engineering and Science, University of Agder, P.O. Box 422, Kristiansand NO. 4604, Norway
}

Received: April 25, 2017 / Accepted: May 03, 2017 / Published: June 30, 2017.

\begin{abstract}
The purpose of this study is to analyze the temperature distribution on the interface between the polymer electrolyte membrane and catalyst layer at the cathode in single cell of polymer electrolyte fuel cell when operated in elevated temperature range than usual. In this study, the interface between the polymer electrolyte membrane and catalyst layer at the cathode is named as reaction surface. This study has considered the 1D multi-plate heat transfer model estimating the temperature distribution on the reaction surface and verified with the 3D numerical simulation model solving many governing equations on the coupling phenomena of the polymer electrolyte fuel cell. The 3D numerical simulation model coverers a half size of actual cell including three straight parts and two turn-back corners, which can display the essential phenomena of single cell. The results from both models/simulations agreed well. The effects of initial operation temperature, flow rate, and relative humidity of supply gas on temperature distribution on the reaction surface have been investigated. Though the effect of flow rate of supply gas on temperature distribution on reaction surface has been small, low relative humidity of supply gas has caused higher temperature on the reaction surface compared to high relative humidity of the supply gas. The temperature rise of reaction surface from initial operation temperature has increased with the increasing in initial operation temperature of cell.
\end{abstract}

Key words: PEFC (polymer electrolyte fuel cell), numerical simulation, temperature distribution, high temperature operation.

\section{Introduction}

PEFC (polymer electrolyte fuel cell) is an attractive and clean electrochemical power generation technology. However, there are some barriers preventing the widespread use of PEFCs. Some of the barriers are the reduction in the power generation performance and life time period, caused by the uneven distributions of a mass concentration and temperature inside the cell of PEFC. Localized increase of temperature is mainly triggered by the local heat generation and poor gas diffusion, which is blocked by the condensed water. This creates the

Corresponding author: Akira Nishimura, Ph.D., associate professor, research fields: heat transfer, fuel cell, photocatalyst and smart city. uneven temperature distribution in the cell of PEFC [1-3].

The temperature distribution in the cell of PEFC is crucial for effective operation of the PEFC. The uneven temperature distribution could cause degradations of the PEM (polymer electrolyte membrane) and catalyst layer. Localized temperature rise would cause thermal decomposition of the PEM. The PEM could also be broken by thermal stress caused by the uneven temperature distribution $[2,4]$. Temperature distribution can also influence the phase change of water/moisture. Moisture content influences the performance of the PEM and gas flows in GDL (gas diffusion layer) and catalyst layer. Therefore, it is important to understand and analyze the temperature distribution in the cell of PEFC, to improve the power 
generation performance and realize the long-life period, which is the main aim of this study.

The temperature distributions on separator's back of single cell of PEFC were measured by thermograph and reported in our previous work [5]. In Ref. [5], the temperature distribution under power generation conditions was measured accurately without disturbing heat and mass transfer and accordingly the sensors were installed. Based on the experimental analysis of the study [5], an empirical model has been developed to predict the temperature distribution on the interface between PEM and catalyst layer at the cathode, which is named as a "reaction surface" in this paper. Through literature survey, it has been observed that there has been no previous study/report on assessing the temperature distribution on reaction surface using the measured temperature data at the separator's back. The temperature distribution on reaction surface can be estimated using the heat transfer model which can be developed with the measured separator back's temperature without difficult and complex temperature measurements.

In previous studies conducted by Nishimura et al. [6, 7], to estimate the temperature distribution inside single cell of the PEFC, a 1D multi-plate heat transfer model, using the temperature data of separator's back measured by thermograph under power generation, has been presented. Since the single cell of PEFC consists components of PEM, catalyst layer, GDL and separator [6, 7], the heat transfer model, assuming the heat transfer through multi-plates for these components of the PEFC cell, has been presented in Refs. [6, 7]. The reaction surface temperature has been calculated using the heat transfer model. This is an innovative approach for identifying the heat transfer mechanism in single cell of PEFC using the developed empirical model based on experimental results.

The empirical model developed by Nishimura et al. $[6,7]$ has been compared with the other heat transfer models [8-10], and it has been observed that the temperature gradients for the targeted regions under the similar operation conditions have been almost the same as reported in Refs. [6, 7]. Thus, it can be believed that, the heat transfer model proposed by Nishimura et al. $[6,7]$ is realistic.

Main aim of the present paper is to predict the temperature distribution on the reaction surface under high temperature operation (such as $363 \mathrm{~K}$ condition), which is the target temperature for a stationary PEFC system during the time from 2020 to 2030 according to the NEDO road map in Japan [11]. If the PEFC system is operated at higher temperature than usual temperature, the following advantages can be obtained [12]: (1) an electrochemical reaction in catalyst layer can be encouraged, and (2) the tolerable concentration of $\mathrm{CO}$, which is by-product from a reforming of hydrocarbon fuel, can be higher. However, the impact of hot spot on PEM becomes bigger under elevated temperature operation condition. In addition, problems such as durability of PEM material, catalyst corrosion, local flow, pressure, temperature, voltage and current un-uniformity inside the fuel cell stack must be solved before commercialization [13]. Some studies [14-26] have investigated PEFC operated under elevated temperature than usual. Although the dynamic power generation characteristics [14-19], the degradation test [20-22], the water distribution [23], the power generation performance under different temperatures, relative humidity, gas flow rate and pressure [24, 25] have been investigated, there have been a few reports $[26,27]$ on temperature distribution in the cell of PEFC. Especially, the temperature distribution on "reaction surface" has not been investigated yet, except in our former study [28] using the proposed heat transfer model. Since the proposed heat transfer model [28], which has been the same as Nishimura et al. [6, 7], is a simple 1D model and has included several assumptions, so it is needed to have more validation of that model. Therefore, this study is investigating the numerical analysis using 3D model in order to assess the temperature distribution on reaction surface. For the numerical simulation, this 
study uses the commercial CFD (computational fluid dynamics) software CFD-ACE+ (ESI Japan), which solves many governing equations on the coupling phenomena in a cell of PEFC such as fluid dynamics, gas diffusion, electrochemical reaction and heat transfer at the same time. The effects of initial operation temperature $\left(T_{\text {ini }}\right)$, flow rate, relative humidity of supply gas on temperature distribution on reaction surface are investigated. In addition, the temperature distributions calculated by the 1D model [28] are also compared with the 3D model.

\section{Calculation Procedures}

\subsection{Numerical Simulation Model and Calculation Conditions}

The numerical analysis using 3D model has been conducted by the CFD-ACE+. This CFD software has the simulation code for PEFC, composed of the equations such as conservation equations of mass, momentum and energy in porous region as well as electrochemical reaction [29]. Although the detailed explanation for all the equations has been given in Ref. [29], the conservation equation for energy can be expressed as $[30,31]$ :

$$
\begin{gathered}
\partial\left\{(1-\varepsilon) \rho_{s} h_{s}+\varepsilon \rho h\right\} / \partial t+\nabla \cdot(\varepsilon \rho U h) \\
=\nabla \cdot q+\varepsilon \tau \nabla U+\varepsilon(\mathrm{d} p / \mathrm{d} t)-I_{T} \eta+|i \cdot i| / \sigma+\dot{S}_{h}
\end{gathered}
$$

where, $\varepsilon$ is porosity; $\rho_{\mathrm{s}}$ is mass density of solid; $h_{\mathrm{s}}$ is enthalpy of solid; $\rho$ is mass density of mixture; $h$ is enthalpy of mixture; $t$ is lapse time; $U$ is fluid velocity vector; $q$ is heat flux; $\tau$ is shear stress tensor; $p$ is absolute pressure; $I_{\mathrm{T}}$ is net transfer current due to electrochemical reaction; $\eta$ is electrode overpotential; $i$ is net current density; $\sigma$ is electrical conductivity; $S_{\mathrm{h}}$ is enthalpy source due to the phase change. The heat flux $q$ is comprised of thermal conduction and species diffusion, and can be expressed as [32]:

$$
q=\lambda \nabla T+\sum_{i=1}^{N_{G}} J_{i} h_{i}
$$

where, $\lambda$ is effective thermal conductivity; $T$ is bulk temperature; $N_{\mathrm{G}}$ is total number of gas species; $J_{i}$ is diffusion flux of $i$-th species; $h_{i}$ is enthalpy of $i$-th species. The effective thermal conductivity of the fluid and solid region can be expressed as [33]:

$$
\lambda=-2 \lambda_{S}+1 /\left\{\varepsilon /\left(2 \lambda_{S}+\lambda_{F}\right)+(1-\varepsilon) / 3 \lambda_{S}\right\}
$$

where, $\lambda_{\mathrm{S}}$ is thermal conductivity of solid in porous region; $\lambda_{\mathrm{F}}$ is thermal conductivity of fluid (or pore) in porous region. Consideration on conservation of enthalpy, heat derived from the shear stress and pressure drop of fluid flow as well as heat derived from the current transfer is the different point in $3 \mathrm{D}$ numerical analysis model compared to the $1 \mathrm{D}$ heat transfer model [28].

The energy conservation equation has been analyzed using a finite volume scheme on arbitrary mesh topology within the framework of the commercial CFD code CFD-ACE+. The governing equations are derived based on the following assumptions [34, 35]:

(1) The volume of condensed water is ignored and the water/moisture moves with gas;

(2) The reduction of the reaction area, caused by the flooding in electrode, is ignored and the diffusion prevention caused by the water condensation is ignored;

(3) Cell voltage is uniform and constant;

(4) The effective porosity and the permeability of the porous media are isotropic;

(5) Heat transfer between the gas and solid phase of porous media is ignored;

(6) Fluid is incompressible Newtonian fluid and ideal gas. Flow condition is a laminar flow;

(7) The distribution of inlet gas flow rate at each side is uniform;

(8) In PEM, ionic conductivity, electro-osmosis coefficient, and water effective diffusion coefficient that depend on the humidity are ignored;

(9) The gas crossing over through PEM is ignored.

The validation of analysis procedure, using these equations, has been already demonstrated [34-38].

Fig. 1 and Table 1 show the simulation model and the specification of cell components used in 3D model 
and 1D heat transfer model [28], respectively. The materials of PEM, catalyst layer, GDL and separator are Nafion 115, compound of platinum and carbon, carbon paper and carbon graphite, respectively. The thickness values listed here are the same as those of the components used by the previous studies $[5,39,40]$.

Tables 2 and 3 list the operation condition of power generation to measure the temperatures used for 1D heat transfer model [28] and calculation conditions for the 3D model, respectively.

As shown in Fig. 1, the model consists of a pair of gas channels and ribs. The thicknesses of cell components are given in Table 1. The temperature data measured by thermograph during power generation experiment have been used as the boundary condition for the separator's back temperature at the anode and cathode. This boundary condition has been the same as the one used in 1D heat transfer model [28]. As shown in Fig. 1, the counter flow has been simulated for the gas flow in the gas channel of separator, which has been followed by the power generation experiment in the previous study [5]. The gas channel length (to $X$-axis direction in Fig. 1) has been set at 50 $\mathrm{mm}$ which was equal to the one straight path length of the actual separator used for power generation experiment [5]. Though the 3D model represents a half size of actual cell, it includes three straight parts and two turn-back corners, which can display the essential phenomena in single cell. Therefore, this study trusts that this $3 \mathrm{D}$ model can predict the temperature distribution on the reaction surface of single cell at elevated temperature than usual.

To investigate the impact of operation condition on the mass and temperature distributions, $T_{\text {ini }}$, flow rate and relative humidity of the supply gas have been varied. Furthermore, the temperature distribution on the reaction surface has been calculated by the numerical simulation using the 3D model and compared to that calculated by the 1D heat transfer model [28].

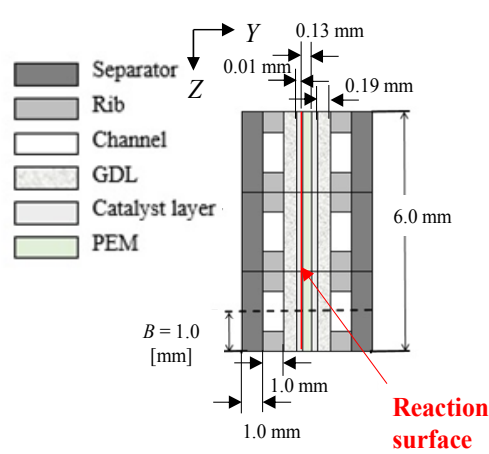

(a)

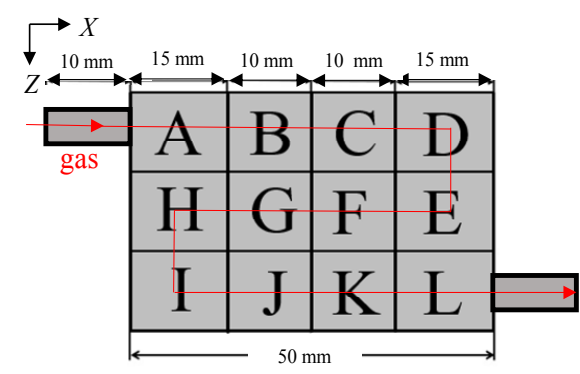

(b)

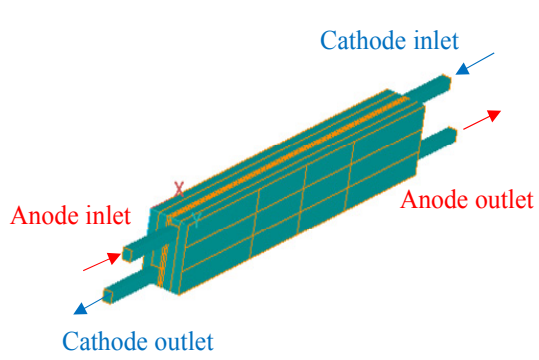

(c)

Fig. 1 3D model for numerical simulation by the CFD-ACE+.

Table 1 Specifications of cell components.

\begin{tabular}{|c|c|c|c|c|}
\hline Parts & Size & Characteristics & Porosity (-) & $\begin{array}{l}\text { Effective thermal } \\
\text { conductivity } \\
\left(\mathrm{W} \cdot \mathrm{m}^{-1} \cdot \mathrm{K}^{-1}\right)\end{array}$ \\
\hline $\begin{array}{l}\text { PEM (polymer } \\
\text { electrolyte membrane) }\end{array}$ & $50.0 \mathrm{~mm} \times 50.0 \mathrm{~mm} \times 0.13 \mathrm{~mm}$ & $\begin{array}{l}\text { Nafion } 115 \\
\text { (produced by Du Pont Corp.) }\end{array}$ & 0.15 & 0.195 \\
\hline Catalyst layer & $\begin{array}{l}50.0 \mathrm{~mm} \times 50.0 \mathrm{~mm} \times 0.01 \mathrm{~mm} \\
\text { (attached with PEM) }\end{array}$ & $\begin{array}{l}\mathrm{Pt} / \mathrm{C} \\
(20 \mathrm{wt} \% \mathrm{Pt} \text { loading })\end{array}$ & 0.78 & 0.27 \\
\hline $\begin{array}{l}\text { GDL (gas diffusion } \\
\text { layer) }\end{array}$ & $50.0 \mathrm{~mm} \times 50.0 \mathrm{~mm} \times 0.17 \mathrm{~mm}$ & $\begin{array}{l}\text { Carbon paper } \\
\text { (TGP-H-060 produced by Toray Corp.) }\end{array}$ & 0.78 & 1.7 \\
\hline Separator & $\begin{array}{l}75.4 \mathrm{~mm} \times 75.4 \mathrm{~mm} \times 2.00 \mathrm{~mm} \\
\text { (thickness of rib part: } 1.00 \mathrm{~mm} \text { ) } \\
\text { (gas supply area: } 50.0 \mathrm{~mm} \times 50.0 \mathrm{~mm} \text { ) }\end{array}$ & Carbon graphite, serpentine & 0.28 & 25 \\
\hline
\end{tabular}


Table 2 Operating conditions of power generation for temperature measurement by thermograph.

\begin{tabular}{|c|c|c|}
\hline $\begin{array}{l}\text { Initial temperature of cell }\left(T_{\text {ini }}\right)(\mathrm{K}) \\
\text { Load current of cell }(\mathrm{A}) \\
\left(\text { Current density of cell }\left(\mathrm{A} / \mathrm{cm}^{2}\right)\right)\end{array}$ & $\begin{array}{l}353,363,373 \\
20 \\
(0.80) \\
\end{array}$ & \\
\hline \multicolumn{3}{|c|}{ Supply gas condition } \\
\hline & Anode & Cathode \\
\hline Gas type & $\mathrm{H}_{2}$ & $\mathrm{O}_{2}$ \\
\hline Temperature of supply gas at inlet $(\mathrm{K})$ & $353,363,373$ & $353,363,373$ \\
\hline Relative humidity of supply gas (\% RH) & 40 (for $363 \mathrm{~K}$ only), 80 & 40 (for $363 \mathrm{~K}$ only), 80 \\
\hline Pressure of supply gas at inlet (absolute) (MPa) & 0.4 & 0.4 \\
\hline Flow rate of supply gas at inlet (NL/min) (Stoichiometric ratio (-)) & $\begin{array}{l}0.210(1.5) \\
0.280(2.0) \\
0.420(3.0)\end{array}$ & $\begin{array}{l}0.105(1.5) \\
0.140(2.0) \\
0.210(3.0) \\
\end{array}$ \\
\hline
\end{tabular}

Table 3 Calculation conditions (upper: for porous media, under: for solid media).

\begin{tabular}{llll}
\hline & GDL & Catalyst layer & PEM \\
\hline Porosity (-) & 0.78 & 0.78 & 0.28 \\
Permeability (through-plane) $\left(\mathrm{m}^{2}\right)$ & $8.69 \times 10^{-12}$ & $8.69 \times 10^{-12}$ & $1.0 \times 10^{-18}$ \\
Permeability (in-plane) $\left(\mathrm{m}^{2}\right)$ & $1.6 \times 10^{-11}$ & $1.6 \times 10^{-11}$ & $1.0 \times 10^{-6}$ \\
Mean particle size $(\mathrm{m})$ & $1.0 \times 10^{-6}$ & $1.0 \times 10^{-6}$ & - \\
Effective catalyst area $\left(1 \cdot \mathrm{m}^{-1}\right)$ & - & 1,000 & 0.195 \\
Thermal conductivity (through-plane) $\left(\mathrm{W} \cdot \mathrm{m}^{-1} \cdot \mathrm{K}^{-1}\right)$ & 1.7 & & $1.0 \times 10^{-20}$ \\
Thermal conductivity (in-plane) $\left(\mathrm{W} \cdot \mathrm{m}^{-1} \cdot \mathrm{K}^{-1}\right)$ & 22 & 0.27 & 53 \\
Electric conductivity (isotropy) $\left(1 \cdot \mathrm{ohm}^{-1} \cdot \mathrm{m}^{-1}\right)$ & 53 & & \\
\hline & Separator & & \\
\hline Density $\left(\mathrm{kg} \cdot \mathrm{m}^{-3}\right)$ & 1,720 & & \\
Electric conductivity $\left(1 \cdot \mathrm{ohm}^{-1} \cdot \mathrm{m}^{-1}\right)$ & $8.33 \times 10^{4}$ & & \\
Specific heat $\left(\mathrm{J} \cdot \mathrm{kg}^{-1} \cdot \mathrm{K}^{-1}\right)$ & 810 & & \\
Thermal conductivity $\left(\mathrm{W} \cdot \mathrm{m}^{-1} \cdot \mathrm{K}^{-1}\right)$ & 25 & & \\
\hline
\end{tabular}

\section{Results and Discussion}

\subsection{Mass and Temperature Distribution-Numerical Analysis Using 3D Model}

Fig. 2 shows the molar concentration distribution of $\mathrm{H}_{2}$ in $\mathrm{Z}$-axis direction on the interface between the PEM and catalyst layer at the anode, where the anode electrochemical reaction occurs. As an example of calculation results, the data obtained at $T_{\text {ini }}$ of $363 \mathrm{~K}$, relative humidity of supply gas of $80 \% \mathrm{RH}$ and stoichiometric ratio of supply gas of 1.5 are shown. In Fig. 2, the molar concentration distributions of $\mathrm{H}_{2}$ at the inlet of position from A to $\mathrm{L}$ are evaluated. Due to the separator configuration, the molar concentration distributions of $\mathrm{H}_{2}$ at the inlet of position $\mathrm{E}$ and $\mathrm{I}$ which are turn-back area are shown in $X$-axis direction. In Fig. 2, $C$ and $R$ represent gas channel and rib of separator, which are $2 \mathrm{~mm}$ and 2 $\mathrm{mm}$, respectively. The origin of Fig. 2 is the extreme left of the molar concentration distribution in $X$-axis direction or $Z$-axis direction to the flow direction. The range from $(C+R) / C=0$ to 0.5 and that from $(C+R) / C$ $=1.5$ to 2.0 indicate the interface between PEM and catalyst layer at anode under the rib, while the range from $(C+R) / C=0.5$ to 1.5 indicates the interface between PEM and catalyst layer at anode under the gas channel.

It has been observed that the molar concentration distribution of $\mathrm{H}_{2}$ is almost even. Since the diffusivity of $\mathrm{H}_{2}$ is good, $\mathrm{H}_{2}$ is spread on the interface between PEM and catalyst layer at anode through GDL and catalyst layer well. It can be seen from Fig. 2 that the molar concentration distribution of $\mathrm{H}_{2}$ is not symmetry slightly. The molar concentration distribution of $\mathrm{H}_{2}$ 

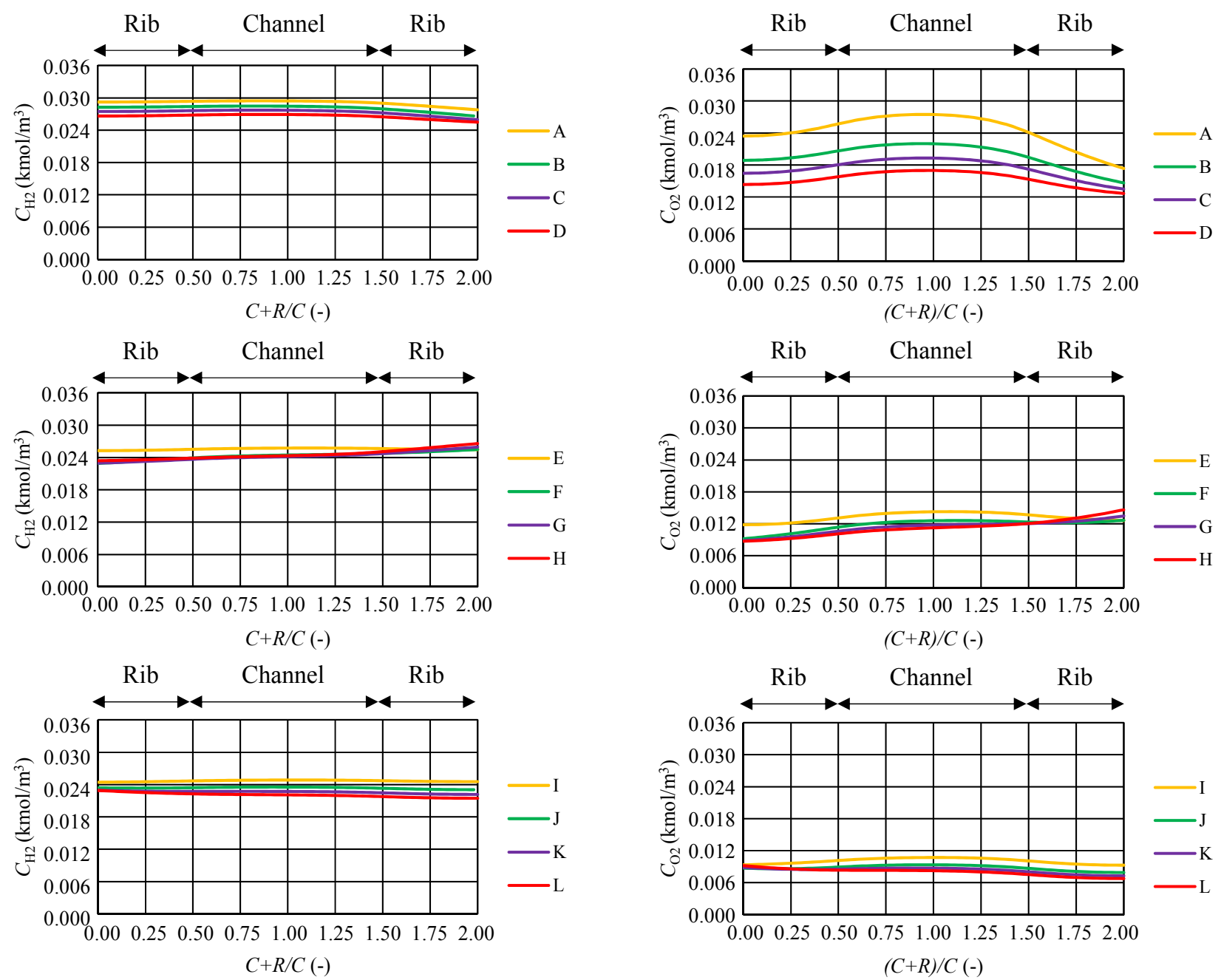

Fig. 2 Molar concentration distribution of $\mathrm{H}_{2}$ on the interface between PEM and catalyst layer at anode calculated using 3D model $\left(T_{\text {in: }}: 363 \mathrm{~K}\right.$; relative humidity of supply gas: $80 \% \mathrm{RH}$; stoichiometric ratio of supply gas: 1.5 ).

under the left rib is higher than that under the right rib in top and bottom sub-figures in Fig. 2, while that under the right rib is higher than that under the left rib in middle sub-figure in Fig. 2. From a viewpoint of the surface consisting of $X$-axis and $Z$-axis, the amount of gas flow at the top edge of the model in gas flow direction is larger, since it is closer to the inlet. On the other hand, the amount of gas flow at the inferior end of the model in gas flow direction is smaller since it is closer to the outlet. Furthermore, it is seen that the molar concentration distribution of $\mathrm{H}_{2}$ decreases along the gas flow from the position $\mathrm{A}$ to $\mathrm{L}$ due to gas consumption.

Fig. 3 Molar concentration distribution of $\mathrm{O}_{2}$ on reaction surface calculated using 3D model $\left(T_{\text {ini }}: 363 \mathrm{~K}\right.$; relative humidity of supply gas: $80 \% \mathrm{RH}$; stoichiometric ratio of supply gas: 1.5$)$.

Fig. 3 shows the molar concentration distribution of $\mathrm{O}_{2}$ in $Z$-axis direction on the reaction surface where the cathode electrochemical reaction occurs. As an example, the data obtained at $T_{\text {ini }}$ of $363 \mathrm{~K}$, relative humidity of supply gas of $80 \% \mathrm{RH}$ and stoichiometric ratio of supply gas of 1.5 are shown. In Fig. 3, the molar concentration distributions of $\mathrm{O}_{2}$ at the inlet of position from A to $\mathrm{L}$ are evaluated. Due to separator configuration, the molar concentration distributions of $\mathrm{O}_{2}$ at the inlet of position $\mathrm{E}$ and I which are turn-back area are shown in the $X$-axis direction.

According to Fig. 3, the molar concentration of $\mathrm{O}_{2}$ under the gas channel is higher than that under the rib. 
In addition, the highest peak of molar concentration of $\mathrm{O}_{2}$ is observed at the gas channel center. Since there is a large molar concentration difference of $\mathrm{O}_{2}$ between the gas channel and the rib at the interface between separator and GDL, the molar concentration of $\mathrm{O}_{2}$ under the gas channel is higher than that under the rib on the reaction surface. The diffusivity of $\mathrm{O}_{2}$ is lower than that of $\mathrm{H}_{2}$, the larger molar concentration difference between gas channel and rib causes compared to Fig. 2. In addition, it can be seen from Fig. 3 that the molar concentration distribution of $\mathrm{O}_{2}$ is not symmetry slightly. The molar concentration distribution of $\mathrm{O}_{2}$ under the left rib is higher than that under the right rib in top and bottom sub-figures in Fig. 3, while that under the right rib is higher than that under the left rib in middle sub-figure in Fig. 3. As the same is discussed for Fig. 2, from a viewpoint of the surface consisting of $X$-axis and $Z$-axis, the amount of gas flow at the top edge of the model in the gas flow direction is larger since it is closer to the inlet. On the other hand, the amount of gas flow at the inferior end of the model in the gas flow direction is smaller since it is closer to the outlet. Furthermore, it is seen that the molar concentration distribution of $\mathrm{O}_{2}$ decreases along the gas flow from the position $\mathrm{A}$ to $\mathrm{L}$ due to the gas consumption.

Fig. 4 shows the molar concentration distribution of water/moisture in $Z$-axis direction on the reaction surface, where the cathode electrochemical reaction occurs. As an example of calculation results, the data obtained at $T_{\text {ini }}$ of $363 \mathrm{~K}$, relative humidity of supply gas of $80 \% \mathrm{RH}$ and stoichiometric ratio of supply gas of 1.5 are shown. The molar concentration distributions of water at the inlet of position from A to $\mathrm{L}$ are evaluated. Due to separator configuration, the molar concentration distributions of water at the inlet of position $\mathrm{E}$ and I which are turn-back area are shown in $X$-axis direction.

According to Fig. 4, the molar concentration of water/moisture under the rib is higher than that under the gas channel. In addition, the highest peak of molar
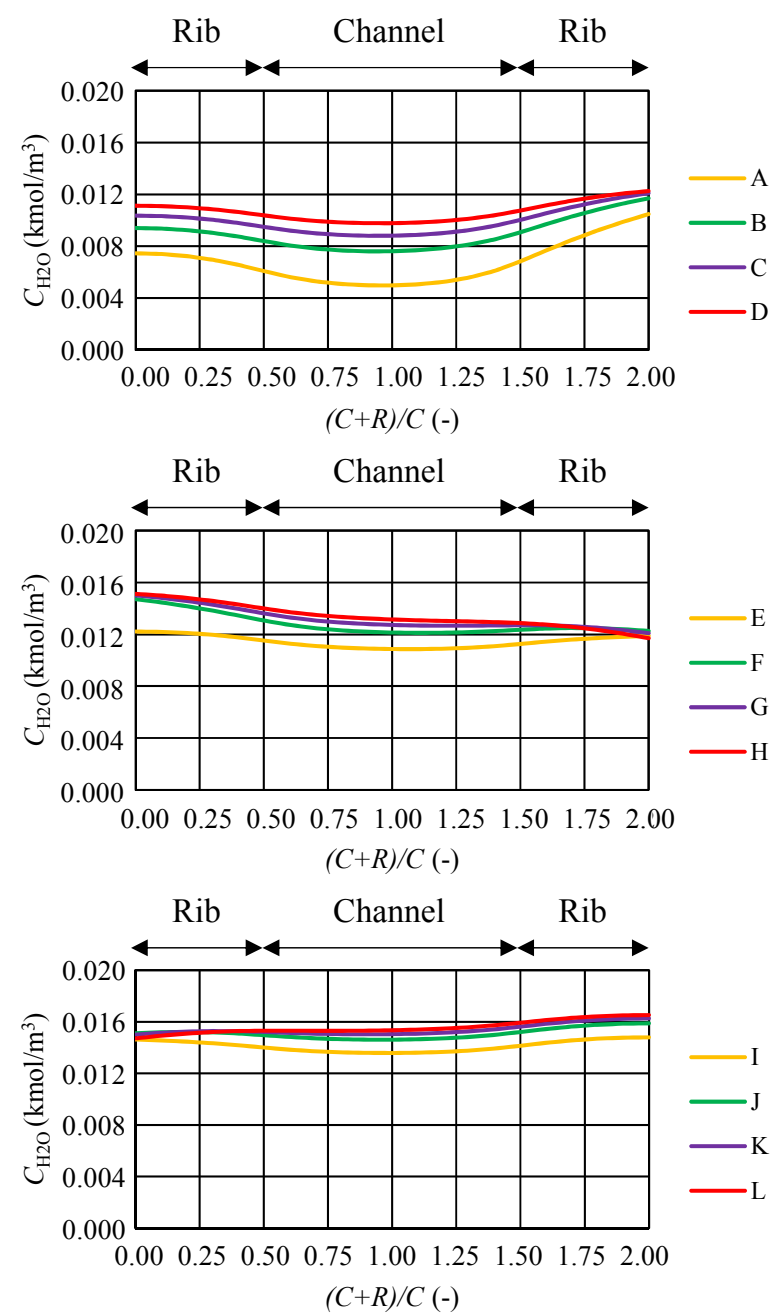

Fig. 4 Molar concentration distribution of water/moisture on reaction surface calculated using $3 \mathrm{D}$ model $\left(T_{\text {ini }}: 363 \mathrm{~K}\right.$; relative humidity of supply gas: $80 \% \mathrm{RH}$; stoichiometric ratio of supply gas: 1.5 ).

concentration of water is observed at the rib center. These tendencies are opposed to the molar concentration distribution of $\mathrm{O}_{2}$. It is thought that, the water under the gas channel is easy to be discharged by $\mathrm{O}_{2}$ passing toward the outlet of cell. Therefore, the molar concentration of water on the reaction surface under the gas channel is lower compared to that under the rib. In addition, it is seen that the molar concentration distribution of water increases along the gas flow from the position $\mathrm{A}$ to $\mathrm{L}$ due to water production by electrochemical reaction. Furthermore, it can be seen from Fig. 4 that the molar concentration distribution of water is not symmetry slightly. The 
molar concentration distribution of water under the right rib is higher than that under the left rib in top and bottom sub-figures in Fig. 4, while that under the left rib is higher than that under the right rib in middle sub-figure in Fig. 4. From a viewpoint of the surface consisting of $X$-axis and $Z$-axis, the amount of accumulated water at the inferior end of the model in gas flow direction is larger, since it is closer to the outlet. On the other hand, the amount of accumulated water at the top edge of the model in gas flow direction is smaller since it is closer to the inlet.

Fig. 5 shows the temperature $\left(T_{\mathrm{r}, \mathrm{CFD}}\right)$ distribution on the reaction surface in $Z$-axis direction. As an example of calculation results, the data obtained at $T_{\mathrm{ini}}$ of $363 \mathrm{~K}$, relative humidity of supply gas of $80 \% \mathrm{RH}$ and stoichiometric ratio of supply gas of 1.5 are shown. The temperature distributions at the inlet of position from A to $\mathrm{L}$ are evaluated. Due to separator configuration, the temperature distributions at the inlet of position $\mathrm{E}$ and I which are turn-back area are shown in $X$ axis direction.

According to Fig. 5, the $T_{\mathrm{r}, \mathrm{CFD}}$ under the rib is higher than that under the gas channel. In addition, the highest peak of $T_{\mathrm{r} \text {, CFD }}$ is observed at the rib center. Since the amount of $\mathrm{O}_{2}$ under the channel is larger compared to that under the rib, it is thought that the convection heat transfer by $\mathrm{O}_{2}$ passing toward the outlet of cell is larger. Therefore, $T_{\mathrm{r}, \mathrm{CFD}}$ under the gas channel becomes lower than that under the rib. In addition, it is seen that $T_{\mathrm{r}, \mathrm{CFD}}$ increases along the gas flow from the position $\mathrm{A}$ to $\mathrm{L}$ due to the power generation advancement by the humidification of produced water.

From Fig. 5, it is observed that the temperature for each position has the distribution within $0.5 \mathrm{~K}$, which is at the similar level to the previous studies $[9,10$, 41]. Consequently, it is thought that, the assumption of 1D multi-plate heat transfer model [28] regarding temperature on reaction surface, i.e., the temperature under the rib is equal to that under the gas channel, is reasonable.
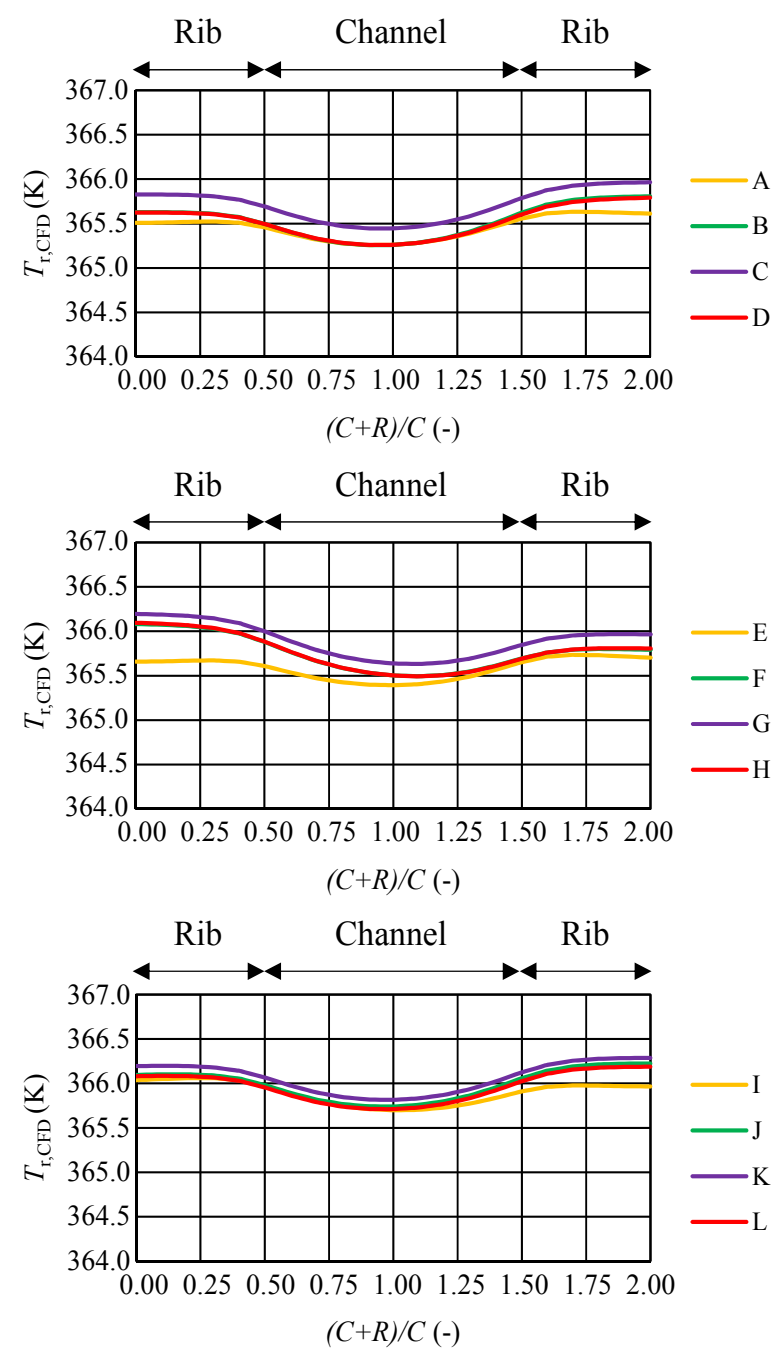

Fig. 5 Temperature distribution on reaction surface calculated using 3D model ( $T_{\text {ini }}: 363 \mathrm{~K}$; relative humidity of supply gas: $80 \% \mathrm{RH}$; stoichiometric ratio of supply gas: 1.5).

\subsection{Effect of Operation Condition on Temperature Distribution-Numerical Analysis Using 3D Model}

The effect of flow rate of supply gas on temperature distribution is investigated on the reaction surface calculated using 3D model. Figs. 6-8 show the temperature distributions on the reaction surface, which are evaluated by $T_{\mathrm{r}, \mathrm{CFD}}-T_{\mathrm{ini}}$, for the different stoichiometric ratios of supply gas at $T_{\text {ini }}$ of $353 \mathrm{~K}$, $363 \mathrm{~K}$ and $373 \mathrm{~K}$, respectively. The relative humidity of supply gas is $80 \%$. Though the temperature distributions at the inlet of position from $\mathrm{A}$ to $\mathrm{L}$ are evaluated, the temperature distributions at the 

Fuel Cell when Operated in Elevated Temperature Range
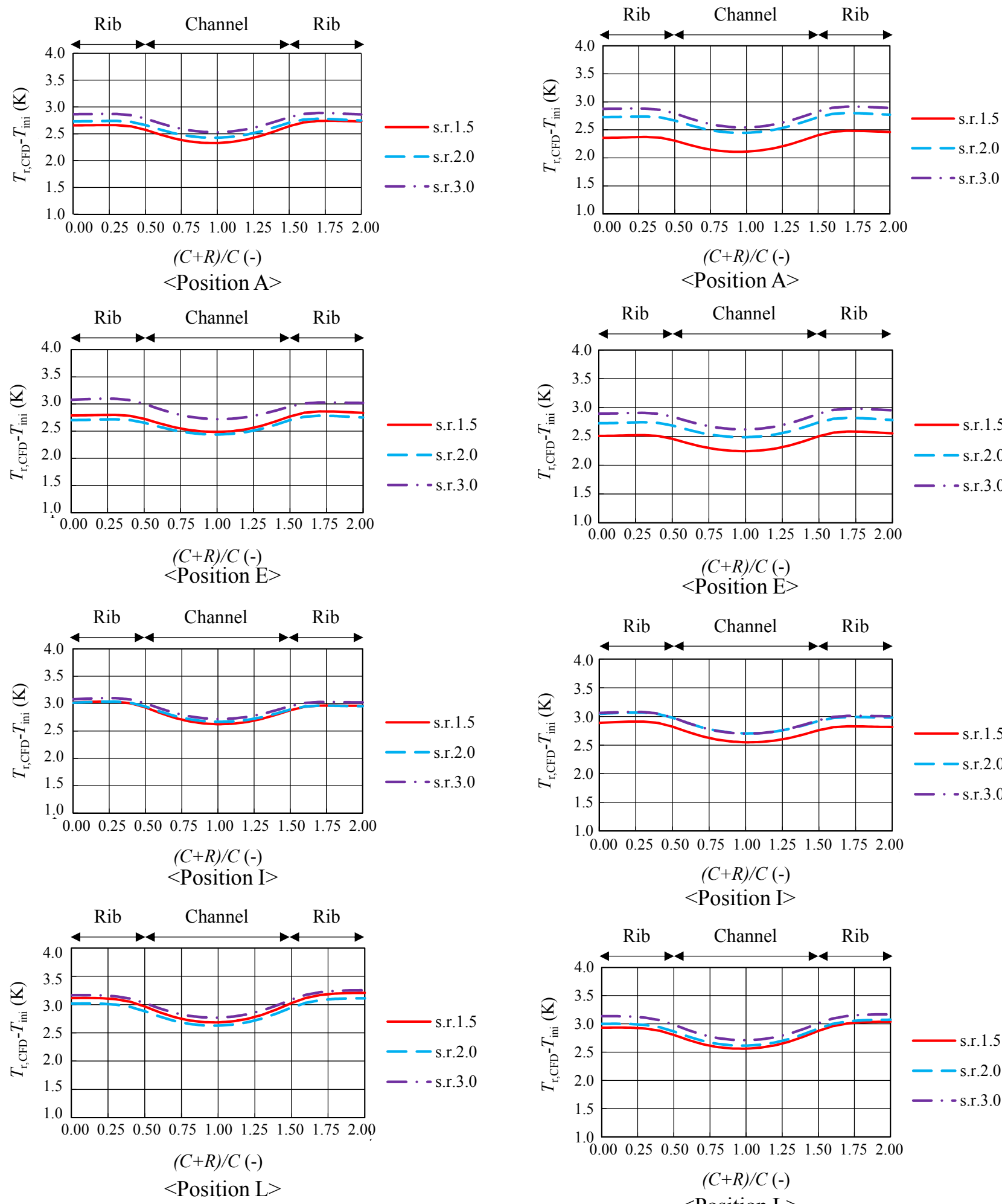

Fig. 6 Effect of flow rate of supply gas on temperature distribution on reaction surface using $3 \mathrm{D}$ model at $T_{\mathrm{ini}}$ of $353 \mathrm{~K}$.
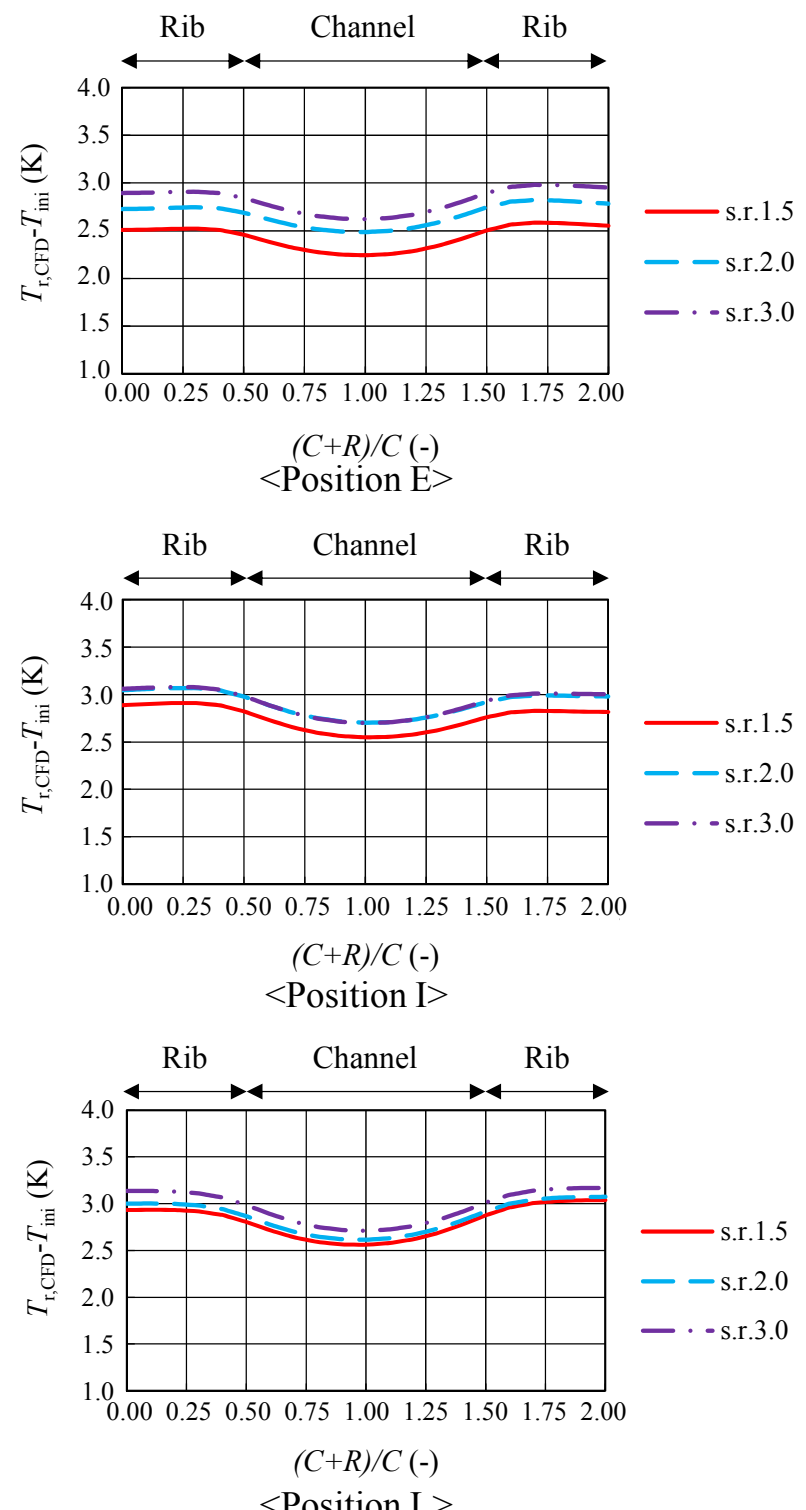

Fig. 7 Effect of flow rate of supply gas on temperature distribution on reaction surface using $3 \mathrm{D}$ model at $T_{\text {ini }}$ of $363 \mathrm{~K}$. 

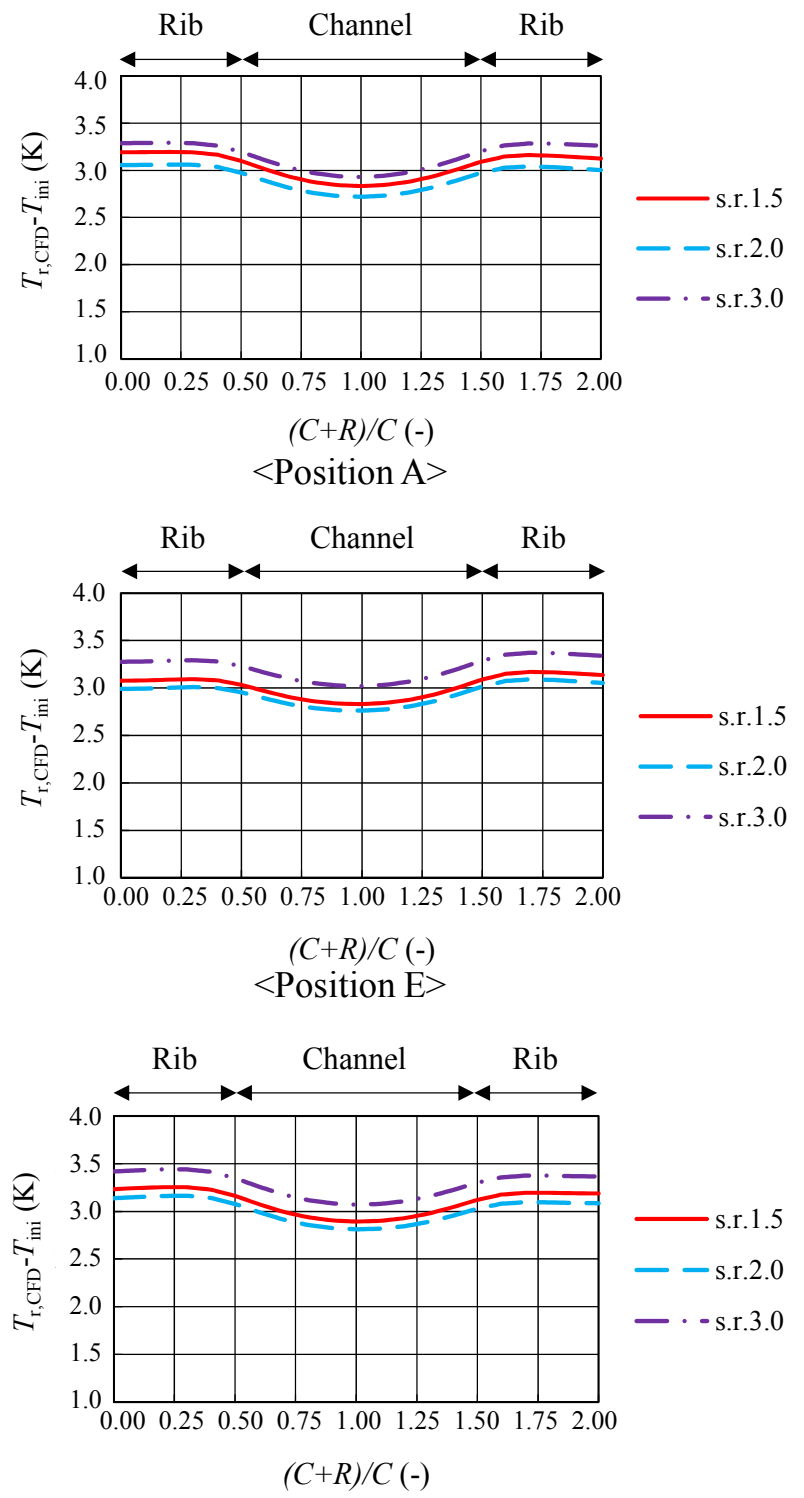

$<$ Position I $>$

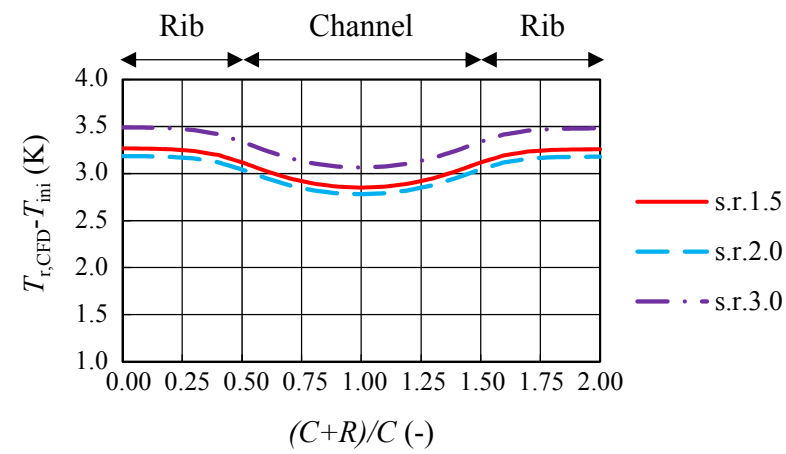

$<$ Position $\mathrm{L}>$

Fig. 8 Effect of flow rate of supply gas on temperature distribution on reaction surface using $3 \mathrm{D}$ model at $T_{\text {ini }}$ of $373 \mathrm{~K}$. inlet of position $\mathrm{E}$ and I which are turn-back area are shown in $X$-axis direction due to separator configuration.

According to Figs. 6-8, the temperature difference among different stoichiometric ratios of supply gas is small, which is below $0.5 \mathrm{~K}$. Since the supply gas is enough for electrochemical reaction even the stoichiometric ratio is 1.5 . It is believed that the difference of heat generated by electrochemical reaction among different stoichiometric ratios is small.

The effects of relative humidity of the supply gas on temperature distribution on the reaction surface are investigated using 3D model. Fig. 9 shows the temperature distributions at $T_{\text {ini }}$ of $363 \mathrm{~K}$ with relative humidity of supply gas of $40 \% \mathrm{RH}$ and $80 \% \mathrm{RH}$. The stoichiometric ratios of supply gas are 1.5, 2.0 and 3.0.

According to Fig. 9, the temperature for $40 \% \mathrm{RH}$ is higher than that for $80 \% \mathrm{RH}$. Since the power generation performance degrades with decreasing relative humidity of supply gas, the energy which cannot be converted to electricity, contributes to increase in heat [28]. Therefore, the temperature on reaction surface under lower relative humidity condition is higher.

The effect of $T_{\text {ini }}$ on temperature distribution is investigated using 3D model. Fig. 10 shows the temperature distributions on the reaction surface evaluated by $T_{\mathrm{r}, \mathrm{CFD}}-T_{\mathrm{ini}}$ at $T_{\text {ini }}$ of $353 \mathrm{~K}, 363 \mathrm{~K}$ and $373 \mathrm{~K}$ with relative humidity of supply gas of $80 \%$ $\mathrm{RH}$. The results with stoichiometric ratio 2.0 of supply gas are shown in Fig. 10.

According to Fig. 10, it is seen that the $T_{\mathrm{r}, \mathrm{CFD}}-T_{\mathrm{ini}}$ at $363 \mathrm{~K}$ is the highest among different $T_{\text {ini. The }}$ difference of $T_{\mathrm{r}, \mathrm{CFD}}-T_{\text {ini }}$ between $353 \mathrm{~K}$ and $363 \mathrm{~K}$ is small, while that between $363 \mathrm{~K}$ and $373 \mathrm{~K}$ is large. The proton conductivity increases by $21 \%$ changing $T_{\text {ini }}$ from $363 \mathrm{~K}$ to $373 \mathrm{~K}$ [42]. On the other hand, the increase in ratio of proton conductivity is $10 \%$, when changing $T_{\text {ini }}$ from $353 \mathrm{~K}$ to $363 \mathrm{~K}$ [42]. Therefore, the power generation performance is improved at $T_{\text {ini }}$ of 


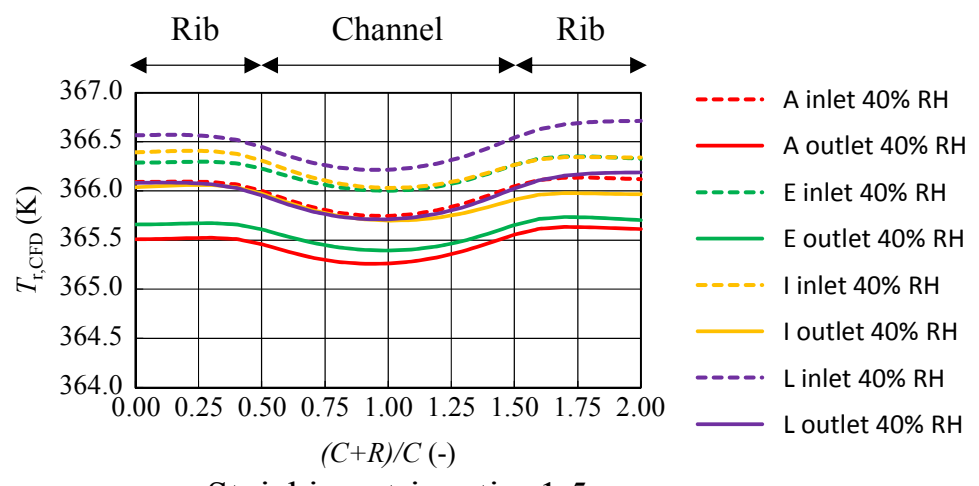

$<$ Stoichiometric ratio: $1.5>$
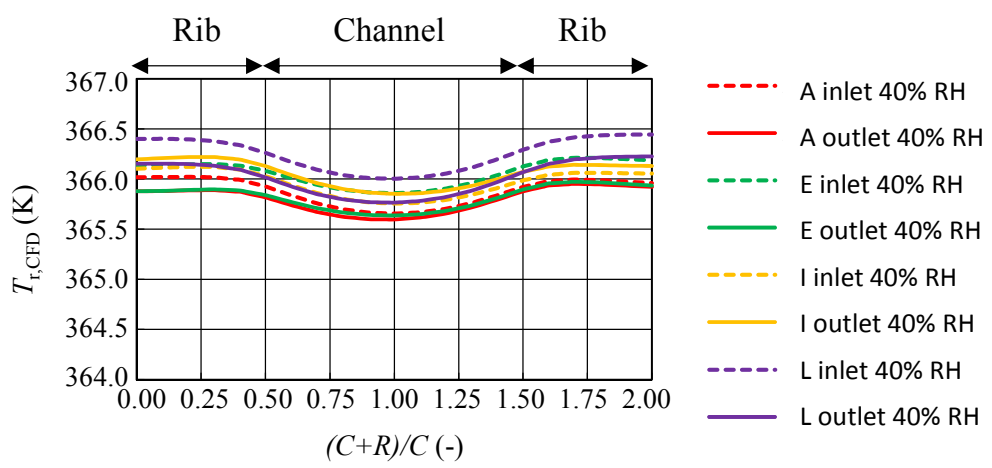

$<$ Stoichiometric ratio: $2.0>$

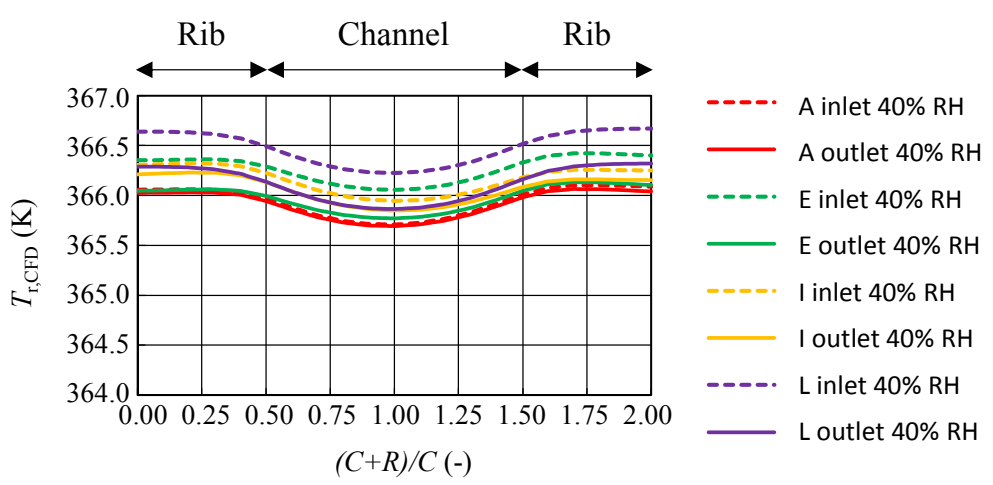

$<$ Stoichiometric ratio: $3.0>$

Fig. 9 Effect of relative humidity of supply gas on temperature distribution on reaction surface using 3D model at $T_{\text {ini }}$ of $363 \mathrm{~K}$.

$373 \mathrm{~K}$, resulting that the temperature rise on the reaction surface becomes high due to the increase in the heat generated by the power generation.

\subsection{Comparison of Temperature Distribution on} Reaction Surface between the 1D Multi-plate Heat Transfer Model and the 3D Model

Tables 4-7 list the temperature rise of the reaction surface from $T_{\text {ini }}$ in the position from A to $\mathrm{L}$ under the conditions that $T_{\mathrm{ini}}$ is $353 \mathrm{~K}$ and the relative humidity of supply gas is $80 \% \mathrm{RH}, T_{\text {ini }}$ is $363 \mathrm{~K}$ and the relative humidity of supply gas is $40 \% \mathrm{RH}, T_{\text {ini }}$ is $363 \mathrm{~K}$ and the relative humidity of supply gas is $80 \% \mathrm{RH}$, and $T_{\text {ini }}$ is $373 \mathrm{~K}$ and the relative humidity of supply gas is $80 \% \mathrm{RH}$, respectively. $T_{\mathrm{r} \text {, CFD }}$ averaged from $Z=0$ $\mathrm{mm}$ to $2.0 \mathrm{~mm}$ at center position of $X$-axis direction for position $\mathrm{A}, \mathrm{B}, \mathrm{C}$ and $\mathrm{D}$, that from $Z=2.0 \mathrm{~mm}$ to $4.0 \mathrm{~mm}$ at center position of $X$-axis direction for position $\mathrm{E}, \mathrm{F}, \mathrm{G}$ and $\mathrm{H}$, that from $Z=4.0 \mathrm{~mm}$ to 6.0 $\mathrm{mm}$ at center position of $X$ axis direction for position 

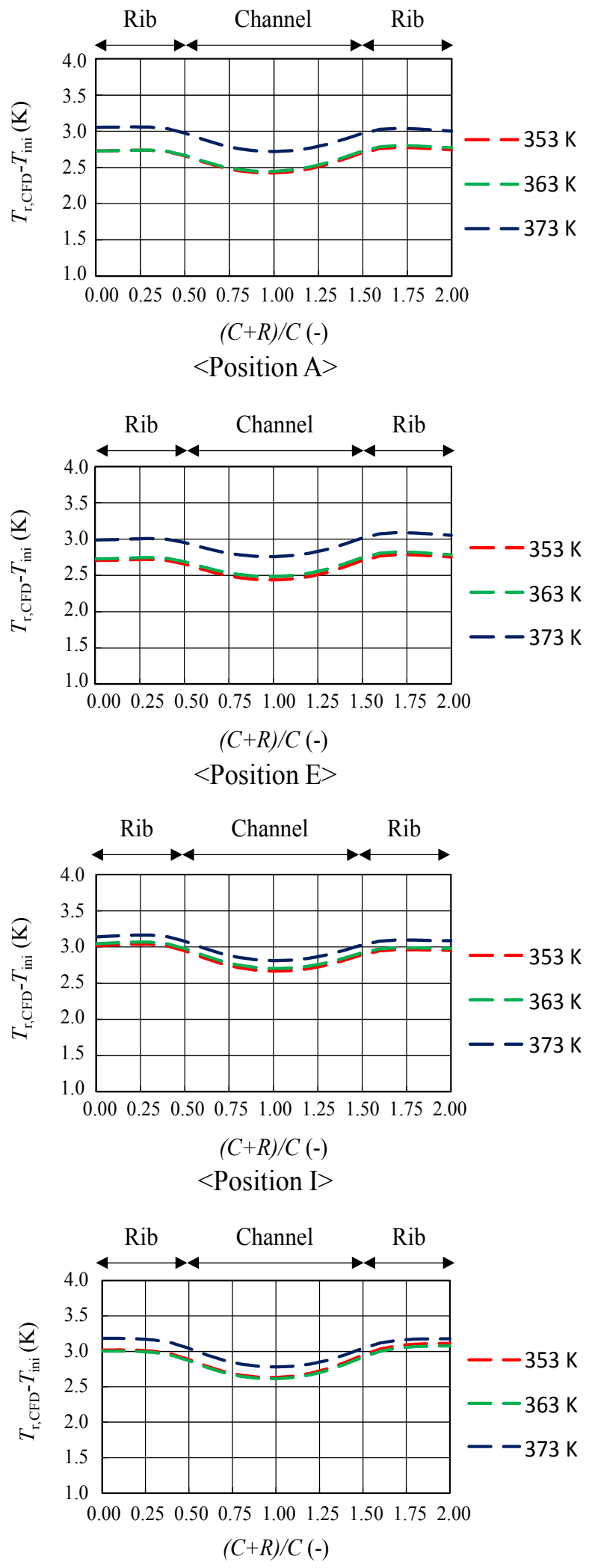

$<$ Position $\mathrm{L}>$

Fig. 10 Effect of $T_{\text {ini }}$ on temperature distribution on reaction surface using $3 \mathrm{D}$ model.
$\mathrm{I}, \mathrm{J}, \mathrm{K}$ and $\mathrm{L}$ are listed in these tables as the representative temperature obtained by the numerical simulation using 3D model. $T_{\mathrm{r}, \mathrm{CFD}}$ at 201 points along $Z$-axis are averaged.

From Table 4, the maximum difference of temperature rise of the reaction surface from $T_{\text {ini }}$ between 1D multi-plate heat transfer model [28] and $3 \mathrm{D}$ numerical simulation model is $0.6 \mathrm{~K}$, which is within the range. The difference of temperature rise of reaction surface from $T_{\text {ini }}$ between $1 \mathrm{D}$ multi-plate heat transfer model [28] and 3D model increases along the gas flow from the position A to L, resulting from that 1D multi-plate heat transfer model treated the water produced by electrochemical reaction as liquid water and the temperature on reaction surface is calculated based on the higher heating value. On the other hand, the 3D model treats the water produced by electrochemical reaction as vapor. Since the molar concentration of water increases along the gas flow from the position $\mathrm{A}$ to $\mathrm{L}$ and liquid water might be generated more, it is believed that the difference of temperature rise of reaction surface from $T_{\text {ini }}$ between 1D multi-plate heat transfer model [28] and 3D model increases along the gas flow from the position $\mathrm{A}$ to $\mathrm{L}$. According to the experimental study [43], the PEM temperature measurement through, the temperature rise of reaction surface from $T_{\text {ini }}$ ranging from $2 \mathrm{~K}$ to 3 $\mathrm{K}$ has been reported under the condition that $T_{\text {ini }}$ was $353 \mathrm{~K}$, the relative humidity of supply gas was $100 \%$ $\mathrm{RH}$, and the cell voltage was $0.2 \mathrm{~V}$. Consequently, it is obvious that, the temperature rise of the reaction surface from $T_{\text {ini }}$ calculated by the 3D model and 1D multi-plate heat transfer model [28] is correct.

It is seen from Table 5 that the maximum difference of temperature rise of the reaction surface from $T_{\text {ini }}$ between 1D multi-plate heat transfer model [28] and 3D model is $1.5 \mathrm{~K}$, while it is seen from Table 6 that the maximum difference is $0.7 \mathrm{~K}$. The maximum difference of temperature rise of the reaction surface from $T_{\text {ini }}$ becomes larger at lower relative humidity of supply gas. It is believed that liquid water is not 
Table 4 Comparison of temperature distribution on reaction surface between 1D multi-plate heat transfer model and 3D model ( $T_{\text {ini: }} 353 \mathrm{~K}$; relative humidity of supply gas: $\left.80 \% \mathrm{RH}\right)$.

\begin{tabular}{|c|c|c|c|c|c|c|c|c|c|c|c|c|c|c|}
\hline \multirow{2}{*}{$\begin{array}{l}\text { Initial operation } \\
\text { temperature, } \\
\text { relative humidity } \\
\text { of supply gas }\end{array}$} & \multirow{2}{*}{$\begin{array}{l}\text { Stoichiometric } \\
\text { ratio }\end{array}$} & \multirow[b]{2}{*}{ Model } & \multicolumn{12}{|c|}{ Temperature rise of reaction surface from initial operation temperature $\left({ }^{\circ} \mathrm{C}\right)$} \\
\hline & & & A & B & $\mathrm{C}$ & $\mathrm{D}$ & $\mathrm{E}$ & $\mathrm{F}$ & $\mathrm{G}$ & $\mathrm{H}$ & I & $\mathrm{J}$ & $\mathrm{K}$ & $\mathrm{L}$ \\
\hline \multirow{6}{*}{$\begin{array}{l}353 \mathrm{~K} \\
80 \% \mathrm{RH}\end{array}$} & \multirow{2}{*}{1.5} & $1 \mathrm{D}$ & 2.4 & 2.5 & 2.5 & 2.4 & 3.0 & 3.1 & 3.1 & 3.0 & 3.1 & 3.3 & 3.4 & 3.3 \\
\hline & & $3 \mathrm{D}$ & 2.5 & 2.5 & 2.5 & 2.5 & 2.7 & 2.8 & 2.7 & 2.7 & 2.8 & 2.9 & 3.0 & 2.9 \\
\hline & \multirow{2}{*}{2.0} & $1 \mathrm{D}$ & 2.5 & 2.6 & 2.5 & 2.3 & 2.9 & 3.1 & 3.1 & 3.0 & 3.2 & 3.4 & 3.4 & 3.4 \\
\hline & & $3 \mathrm{D}$ & 2.5 & 2.5 & 2.5 & 2.4 & 2.7 & 2.7 & 2.7 & 2.7 & 2.8 & 2.9 & 2.9 & 2.8 \\
\hline & \multirow{2}{*}{3.0} & $1 \mathrm{D}$ & 2.7 & 2.8 & 2.8 & 2.8 & 3.2 & 3.3 & 3.3 & 3.1 & 3.5 & 3.6 & 3.5 & 3.3 \\
\hline & & $3 \mathrm{D}$ & 2.6 & 2.7 & 2.7 & 2.6 & 2.8 & 2.9 & 2.9 & 2.8 & 2.9 & 3.0 & 3.1 & 3.0 \\
\hline
\end{tabular}

Table 5 Comparison of temperature distribution on reaction surface between 1D multi-plate heat transfer model and 3D model ( $T_{\text {ini: }} 363 \mathrm{~K}$; relative humidity of supply gas: $\left.40 \% \mathrm{RH}\right)$.

\begin{tabular}{|c|c|c|c|c|c|c|c|c|c|c|c|c|c|c|}
\hline \multirow{2}{*}{$\begin{array}{l}\text { Initial operation } \\
\text { temperature, } \\
\text { relative humidity } \\
\text { of supply gas }\end{array}$} & \multirow{2}{*}{$\begin{array}{l}\text { Stoichiometric } \\
\text { ratio }\end{array}$} & \multirow{2}{*}{ Model } & \multicolumn{12}{|c|}{ Temperature rise of reaction surface from initial operation temperature $\left({ }^{\circ} \mathrm{C}\right)$} \\
\hline & & & A & $\mathrm{B}$ & $\mathrm{C}$ & $\mathrm{D}$ & $\mathrm{E}$ & $\mathrm{F}$ & $\mathrm{G}$ & $\mathrm{H}$ & I & $\mathrm{J}$ & $\mathrm{K}$ & $\mathrm{L}$ \\
\hline \multirow{6}{*}{$\begin{array}{l}363 \mathrm{~K}, \\
40 \% \mathrm{RH}\end{array}$} & \multirow{2}{*}{1.5} & $1 \mathrm{D}$ & 3.5 & 3.7 & 3.6 & 3.4 & 3.9 & 4.1 & 4.2 & 4.1 & 4.4 & 4.5 & 4.3 & 4.1 \\
\hline & & $3 \mathrm{D}$ & 2.7 & 2.8 & 2.8 & 2.8 & 3.1 & 3.0 & 3.0 & 2.9 & 3.1 & 3.3 & 3.3 & 3.3 \\
\hline & \multirow{2}{*}{2.0} & $1 \mathrm{D}$ & 3.5 & 3.7 & 3.6 & 3.5 & 3.7 & 4.0 & 4.1 & 4.0 & 4.1 & 4.2 & 4.1 & 3.8 \\
\hline & & $3 \mathrm{D}$ & 2.6 & 2.8 & 2.8 & 2.7 & 2.9 & 3.0 & 2.8 & 2.7 & 2.7 & 2.7 & 3.1 & 3.0 \\
\hline & \multirow{2}{*}{3.0} & $1 \mathrm{D}$ & 3.9 & 4.0 & 3.9 & 3.8 & 4.2 & 4.4 & 4.5 & 4.4 & 4.5 & 4.7 & 4.6 & 4.2 \\
\hline & & $3 \mathrm{D}$ & 2.7 & 2.9 & 3.0 & 2.9 & 3.1 & 3.2 & 3.1 & 2.8 & 3.0 & 3.3 & 3.4 & 3.3 \\
\hline
\end{tabular}

Table 6 Comparison of temperature distribution on reaction surface between 1D multi-plate heat transfer model and 3D model ( $T_{\text {ini: }} 363 \mathrm{~K}$; relative humidity of supply gas: $\left.80 \% \mathrm{RH}\right)$.

\begin{tabular}{|c|c|c|c|c|c|c|c|c|c|c|c|c|c|c|}
\hline \multirow{2}{*}{$\begin{array}{l}\text { Initial operation } \\
\text { temperature, } \\
\text { relative humidity } \\
\text { of supply gas }\end{array}$} & \multirow{2}{*}{$\begin{array}{l}\text { Stoichiometric } \\
\text { ratio }\end{array}$} & \multirow[b]{2}{*}{ Model } & \multicolumn{12}{|c|}{ Temperature rise of reaction surface from initial operation temperature $\left({ }^{\circ} \mathrm{C}\right)$} \\
\hline & & & $\mathrm{A}$ & B & $\mathrm{C}$ & $\mathrm{D}$ & $\mathrm{E}$ & $\mathrm{F}$ & $\mathrm{G}$ & $\mathrm{H}$ & I & $\mathrm{J}$ & $\mathrm{K}$ & $\mathrm{L}$ \\
\hline \multirow{6}{*}{$\begin{array}{l}363 \mathrm{~K}, \\
80 \% \mathrm{RH}\end{array}$} & \multirow{2}{*}{1.5} & $1 \mathrm{D}$ & 2.6 & 2.8 & 2.7 & 2.7 & 3.0 & 3.2 & 3.2 & 3.0 & 3.3 & 3.5 & 3.5 & 3.4 \\
\hline & & $3 \mathrm{D}$ & 2.2 & 2.6 & 2.5 & 2.2 & 2.5 & 2.7 & 2.8 & 2.5 & 2.8 & 2.9 & 2.9 & 2.7 \\
\hline & \multirow{2}{*}{2.0} & $1 \mathrm{D}$ & 2.6 & 2.7 & 2.7 & 2.6 & 3.2 & 3.2 & 3.1 & 3.0 & 3.3 & 3.4 & 3.4 & 3.3 \\
\hline & & $3 \mathrm{D}$ & 2.5 & 2.6 & 2.6 & 2.5 & 2.7 & 2.8 & 2.7 & 2.7 & 2.8 & 2.9 & 2.9 & 2.8 \\
\hline & \multirow{2}{*}{3.0} & $1 \mathrm{D}$ & 2.9 & 3.0 & 3.0 & 2.9 & 3.4 & 3.4 & 3.4 & 3.3 & 3.4 & 3.6 & 3.5 & 3.3 \\
\hline & & $3 \mathrm{D}$ & 2.7 & 2.7 & 2.8 & 2.6 & 2.8 & 2.9 & 2.9 & 2.8 & 2.8 & 3.0 & 3.0 & 2.9 \\
\hline
\end{tabular}

Table 7 Comparison of temperature distribution on reaction surface between 1D multi-plate heat transfer model and 3D model ( $T_{\text {ini: }}: 373 \mathrm{~K}$; relative humidity of supply gas: $\left.80 \% \mathrm{RH}\right)$.

\begin{tabular}{|c|c|c|c|c|c|c|c|c|c|c|c|c|c|c|}
\hline \multirow{2}{*}{$\begin{array}{l}\text { Initial operation } \\
\text { temperature, } \\
\text { relative humidity } \\
\text { of supply gas }\end{array}$} & \multirow{2}{*}{$\begin{array}{l}\text { Stoichiometric } \\
\text { ratio }\end{array}$} & \multirow{2}{*}{ Model } & \multicolumn{12}{|c|}{ Temperature rise of reaction surface from initial operation temperature $\left({ }^{\circ} \mathrm{C}\right)$} \\
\hline & & & A & B & $\mathrm{C}$ & $\mathrm{D}$ & $\mathrm{E}$ & $\mathrm{F}$ & G & $\mathrm{H}$ & I & $\mathrm{J}$ & $\mathrm{K}$ & $\mathrm{L}$ \\
\hline \multirow{6}{*}{$\begin{array}{l}373 \mathrm{~K}, \\
80 \% \mathrm{RH}\end{array}$} & \multirow{2}{*}{1.5} & $1 \mathrm{D}$ & 2.8 & 3.0 & 3.0 & 3.0 & 3.3 & 3.3 & 3.3 & 3.1 & 3.2 & 3.3 & 3.3 & 3.2 \\
\hline & & $3 \mathrm{D}$ & 3.0 & 3.0 & 3.0 & 2.8 & 3.0 & 3.1 & 3.1 & 3.0 & 3.0 & 3.1 & 3.1 & 3.0 \\
\hline & \multirow{2}{*}{2.0} & $1 \mathrm{D}$ & 2.6 & 2.7 & 2.8 & 2.8 & 3.1 & 3.2 & 3.1 & 2.9 & 3.0 & 3.1 & 3.1 & 3.0 \\
\hline & & $3 \mathrm{D}$ & 2.8 & 2.9 & 2.9 & 2.7 & 2.9 & 3.0 & 3.0 & 2.9 & 2.9 & 3.1 & 3.1 & 3.0 \\
\hline & \multirow{2}{*}{3.0} & $1 \mathrm{D}$ & 2.8 & 3.2 & 3.1 & 2.7 & 3.2 & 3.4 & 3.4 & 3.0 & 3.3 & 3.4 & 3.4 & 3.3 \\
\hline & & $3 \mathrm{D}$ & 3.1 & 3.2 & 3.2 & 3.0 & 3.2 & 3.3 & 3.3 & 3.1 & 3.2 & 3.3 & 3.3 & 3.3 \\
\hline
\end{tabular}


produced easily at relative humidity of supply gas of $40 \%$ RH. However, 1D multi-plate heat transfer model [28] has calculated the temperature on the reaction surface assuming liquid water production based on the higher heating value. Therefore, the temperature on reaction surface calculated by $1 \mathrm{D}$ multi-plate heat transfer model [28] might be higher than actual.

From Table 7, the maximum difference of the temperature rise of the reaction surface from $T_{\text {ini }}$ between 1D multi-plate heat transfer model [28] and $3 \mathrm{D}$ model is $0.3 \mathrm{~K}$, which is justified. 1D multi-plate heat transfer model [28] has calculated the temperature on the reaction surface assuming the vapor production by electrochemical reaction at $T_{\text {ini }}$ of $373 \mathrm{~K}$, which is based on the lower heating value. Since the calculation condition regarding water production is the same between 1D multi-plate heat transfer model [28] and 3D model, the calculated temperatures for two models are justified.

From this study, it has been accessed that the temperature distribution on the reaction surface calculated by the 1D multi-plate heat transfer model [28] has been validated by the numerical simulation using the 3D model.

\section{Conclusions}

This study examines the numerical analysis using $3 \mathrm{D}$ model to evaluate the temperature distribution on the reaction surface. In addition, $T_{\text {ini }}$, flow rate and relative humidity of supply gas have been varied to investigate the effect of operation condition on the temperature distribution on the reaction surface. The temperature distribution on the reaction surface calculated using 3D model is compared to that calculated by the 1D heat transfer model [28]. From the analysis of results of this study, the following conclusions have been obtained:

(1) Though $T_{\mathrm{r}, \mathrm{CFD}}$ under the rib is higher than that under the gas channel, the temperature for each position has the distribution within $0.5 \mathrm{~K}$, which can be treated as even temperature distribution.

(2) The effect of flow rate of supply gas on temperature distribution on the reaction surface is small.

(3) The temperature on the reaction surface under low relative humidity condition is higher than high relative humidity condition.

(4) The $T_{\mathrm{r}, \mathrm{CFD}}-T_{\text {ini }}$ at $363 \mathrm{~K}$ is the highest among different $T_{\text {ini }}$. The difference of $T_{\mathrm{r}, \mathrm{CFD}}-T_{\text {ini }}$ between $353 \mathrm{~K}$ and $363 \mathrm{~K}$ is small, while that between $363 \mathrm{~K}$ and $373 \mathrm{~K}$ is large.

(5) The temperature distribution on the reaction surface calculated by the 1D multi-plate heat transfer model [28] has been validated by the numerical analysis using a 3D model, and the maximum difference between two models becomes larger at lower relative humidity condition.

\section{Acknowledgments}

The authors gratefully acknowledge support of the Mie Prefecture Industrial Research Institute for this study.

\section{References}

[1] Weber, A. Z., Darling, R. M., and Newman, J. 2004. "Modeling Two-Phase Behavior in PEFCs." Journal of Electrochemical Society 151 (10): A1715-27.

[2] Wang, M., Guo, H., and Ma, C. 2006. "Temperature Distribution on the MEA Surface of a PEMFC with Serpentine Channel Flow Bed." Journal of Power Sources 157 (1): 181-7.

[3] Ito, K. 2008. "Temperature Distribution Measurement in Through-Plane Direction for PEFC." Japan Society of Mechanical Engineers 111 (1079): 42-4.

[4] Tsuji, K. 2008. "Domestic Fuel Cell Co-generation System Entering Real Commercial Stage.” Hydrogen Energy System 33 (3): 93-6.

[5] Nishimura, A., Shibuya, K., Morimoto, A., Tanaka, S., Hirota, M., Nakamura, Y., Kojima, M., Narita, M., and Hu, E. 2012. "Dominant Factor and Mechanism of Coupling Phenomena in Single Cell of Polymer Electrolyte Fuel Cell." Applied Energy 90 (1): 73-9.

[6] Nishimura, A., Iio, K., Baba, M., Yamauchi, T., Hirota, M., and Hu, E. 2014. "Modeling of Heat Transfer in Single Cell of Polymer Electrolyte Fuel Cell by Means of 

Fuel Cell when Operated in Elevated Temperature Range

Temperature Data Measured by Thermograph." Journal of Chemical Engineering of Japan 47 (7): 521-9.

[7] Nishimura, A., Fukuoka, T., Baba, M., Hirota, M., and Hu, E. 2015. "Clarification on Temperature Distribution in Single Cell of Polymer Electrolyte Fuel Cell under Different Operation Conditions by Means of 1D Multi-plate Heat-Transfer Model." Journal of Chemical Engineering of Japan 48 (10): 862-71.

[8] Khandelwal, M., and Mench, M. M. 2006. "Direct Measurement of Through-Plane Thermal Conductivity and Contact Resistance in Fuel Cell Materials." Journal of Power Sources 161 (2): 1106-15.

[9] Kawase, M., Inagaki, T., Kawashima, S., and Miura, K. 2009. "Effective Thermal Conductivity of Gas Diffusion Layer in Through-Plane Direction.” ECS Transactions 25 (1): 1529-37.

[10] Jung, C. Y., Shim, H. S., Koo, S. M., Lee, S. H., and Yi, S. C. 2012. "Investigation of the Temperature Distribution in Proton Exchange Membrane Fuel Cell." Applied Energy 93 (May): 733-41.

[11] NEDO (New Energy and Industry Technology Development Organization). 2010. "Road Map 2010 of NEDO Fuel Cell and Hydrogen Technology Development." Department of Fuel Cell and Hydrogen Technology. Accessed June 6, 2016. http://www.nedo.go.jp/content/100642949.pdf.

[12] Li, Q., He, R., Jensen, J. O., and Bjerrum, N. J. 2003. "Approaches and Recent Development Polymer Electrolyte Membrane for Fuel Cells Operating above $100{ }^{\circ} \mathrm{C} . "$ Chemical of Materials 15 (26): 4896-915.

[13] Lee, C. Y., Weng, F. B., Kuo, Y. W., Tsai, C. H., Cheng, Y. T., Cheng, C. K., and Lin, J. T. 2016. "In-Situ Measurement of High-Temperature Proton Exchange Membrane Fuel Cell Stack Using Flexible Five-in-One Micro-Sensor." Sensors 16 (10): 1731.

[14] Jheng, L. C., Chang, W. J. Y., Hsu, S. L. C., and Cheng, P. Y. 2016. "Durability of Symmetrically and Asymmetrically Porous Polybenzimdazole Membranes for High Temperature Proton Exchange Membrane Fuel Cells." Journal of Power Sources 323 (August): 57-66.

[15] Ruiu, T., Dreizler, A. M., Mitzel, J., and Gulzow, E. 2016. "Evaluation of a $2.5 \mathrm{~kW}_{\mathrm{el}}$ Automotive Low Tempearture PEM Fuel Cell Stack with Extended Operating Temperature Range up to $120{ }^{\circ} \mathrm{C}$." Journal of Power Sources 303 (January): 257-66.

[16] Nguyen, G., Sahlin, S., Andreasen, S. J., Shaffer, B., and Brouwer, J. 2016. "Dynamic Modeling and Experimental Investivation of a High Temperature PEM Fuel Cell Stack." International Journal of Hydrogen Energy 41 (8): 4729-39.

[17] Huang, H., Zhou, Y., Deng, H., Xie, X., Du, Q., Yin, Y., and Jiao, K. 2016. "Modeling of High Temperature Proton Exchange Membrane Fuel Cell Start-Up Processes." International Journal of Hydrogen Energy 41 (4): 3113-27.

[18] Zhang, C., Yu, T., Yi, J., Liu, Z., Raj, K. A. R., Xia, L., Tu, Z., and Chan, S. H. 2016. "Investigation of Heating and Cooling in a Stand-Alone High Temperature PEM Fuel Cell System." Energy Conversion and Management 129 (December): 36-42.

[19] Kim, H. S., Jeon, S. W., Cha, D., and Kim, Y. 2016. "Numerical Analysis of a High-Temperature Proton Exchange Membrane Fuel Cell under Humidified Operation with Stepwise Reactant Supply." International Journal of Hydrogen Energy 41 (31): 13657-65.

[20] Pinar, F. J., Rastedt, M., Pilinski, N., and Wagner, P. 2016. "Effect of Idling Temperature on High Temperature Polymer Electrolyte Membrane Fuel Cell Degradation under Simulated Start/Stop Cycling Conditions." International Journal of Hydrogen Energy 41 (42): 19463-74.

[21] Araya, S. S., Zhou, F., Liso, V., Sahlin, S. L., Vang, J. R., Thomas, S., Gao, X., Jeppesen, C., and Kar, S. K. 2016. "A Comprehensive Review of PBI-Based High Temperature PEM Fuel Cells." International Journal of Hydrogen Energy 41 (46): 21310-44.

[22] Nandjou, F., Poirot-Crouvezier, J. P., Chandesris, M., and Bultel, Y. 2016. “A Pseudo-3D Model to Investigate Heat and Water Transport in Large Area PEM Fuel Cells-Part 1: Model Development and Validation." International Journal of Hydrogen Energy 41 (34): 15545-61.

[23] Reimer, U., Ehlert, J., Janssen, H., and Lehnert, W. 2016. "Water Distribution in High Temperature Polymer Electrolyte Fuel Cells." International Journal of Hydrogen Energy 41 (3): 1837-45.

[24] Sezgin, B., Caglayan, D. G., Devrim, Y., Steenberg, T., and Eroglu, I. 2016. "Modeling and Sensitive Analysis of High Temperature PEM Fuel Cells by Using Comsol Multiphysics." International Journal of Hydrogen Energy 41 (23): 10001-9.

[25] Waller, M. G., Walluk, M. R., and Trabold, T. A. 2016. "Performance of High Temperature PEM Fuel Cell Materials. Part 1: Effects of Temperature, Pressure and Anode Dilution." International Journal of Hydrogen Energy 41 (4): 2944-54.

[26] Rasheed, R. K. A., and Chan, S. H. 2016. "Analysis of Steady State Heating Configuration for High-Temperature Proton Exchange Membrane Fuel Cell Based on Multi-Physical Numerical Modeling." Electrochimica Acta 222 (December): 280-92.

[27] Nishimura, A., Yoshimura, M., Mahadi, A. M., Hirota, M., and Kolhe, M. L. 2016. "Impact of Operation 

Fuel Cell when Operated in Elevated Temperature Range

Condition on Temperature Distribution in Single Cell of Polymer Electrolyte Fuel Cell Operated at Higher Temperature than Usual." Mechanical Engineering Journal 3 (5): 1-14.

[28] Nishimura, A., Osada, K., Tsunoda, T., Yoshimura, M., Hirota, M., and Hu, E. 2016. "Analysis on Temperature Distribution in Single Cell of Polymer Electrolyte Fuel Cell when Operated in High Temperature Range." Journal of Energy and Power Engineering 10 (8): 453-64.

[29] Nishimura, A., Morimoto, A., Tanaka, S., Oshima, A., Hirota, M., Tohma, E., Kimura, Y., and Narita, M. 2012. "Influence of Cell Components Structure on Heat and Mass Transfer Phenomena in Single-Cell PEFC." Journal of Energy and Power Engineering 6 (4): 504-18.

[30] Bird, R. B., Stewart, W. E., and Lightfoot, E. N. 1960. Transport Phenomena. Tokyo: Toppan Company Ltd., 81-2.

[31] Kaviany, M. 1999. Principles of Heat Transfer in Porous Media. New York: Springer, 145-8, 166-72.

[32] Gurau, V., Liu, H., and Kakac, S. 1998. "Two-Dimensional Model for Proton Exchange Membrane Fuel Cells." AIChE Journal 44 (11): 2410-22.

[33] Dagan, G. 1989. Flow and Transport in Porous Formations. Berlin: Splinger-Verlag Berlin Heidelberg, 55-61, 82-3, 89-91.

[34] Mazumdar, S., and Cole, J. V. 2003. "Rigorous 3-D Mathematical Modeling of PEM Fuel Cells: I. Model Predictions without Liquid Water Transport." Journal of the Electrochemical Society 150 (11): A1503-9.

[35] Mazumdar, S., and Cole, J. V. 2003. "Rigorous 3-D Mathematical Modeling of PEM Fuel Cells: II. Model Predictions with Liquid Water Transport." Journal of the Electrochemical Society 150 (11): A1510-7.

[36] Senn, S. M., and Poulikakos, D. 2004. "Polymer
Electrolyte Fuel Cells with Porous Materials as Fluid Distributors and Comparisons with Traditional Channeled Systems." Journal of Heat Transfer 126 (3): 410-8.

[37] Wang, Y., and Wang, C. Y. 2006. "A Nonisothermal Two-Phase Model for Polymer Electrolyte Fuel Cells." Journal of the Electrochemical Society 153 (6): A1193-200.

[38] Wu, H., Berg, P., and Li, X. 2008. "Steady and Unsteady 3D Non-isothermal Modeling of PEM Fuel Cells with the Effect of Non-equilibrium Phase Transfer." In Proceedings of the 4th International Green Energy Conference, 200-11.

[39] Hwang, S. S., Han, S. S., Lee, P. H., and Park, B. I. 2010. "Transient Performance Behavior of Proton Exchange Membrane Fuel Cell by Configuration of Membrane and Gas Diffusion Layer." Journal of Thermal Science and Technology 5 (1): 165-77.

[40] Wu, H., Berg, P., and Li, X. 2010. "Steady and Unsteady 3D Non-isothermal Modeling of PEM Fuel Cells with the Effect of Non-equilibrium Phase Transfer." Applied Energy 87 (9): 2778-84.

[41] Oshima, A., Nishimura, A., Morimoto, A., Tanaka, S., Hirota, M., and Narita, M. 2010. "Theoretical Investigation on Influence of Inflow Gas Condition and Gas Channel Structure of Separator on Mass and Temperature Distribution in Single Cell of Polymer Electrolyte Fuel Cell." In Proceedings of the Mechanical Engineering Congress, 203-4.

[42] Springer, T. E., Zawodzinski, T. A., and Gottesfeld, S. 1991. "Polymer Electrolyte Fuel Cell Model." Journal of Electrochemical Society 138 (8): 2334-41.

[43] He, S., Mench, M. M., and Tadigadapa, S. 2006. "Thin Film Temperature Sensor for Real-Time Measurement of Electrolyte Temperature in a Polymer Electrolyte Fuel Cell." Sensors and Actuators A 125 (2): 170-7. 